\title{
Where My Heart Belongs
}

\author{
Hartanta, A. \\ English for Creative Industry, Faculty of Letters, Petra Christian University, Siwalankerto 121-131, Surabaya \\ 60236, East Java, INDONESIA \\ Email:m11414005@john.petra.ac.id
}

\begin{abstract}
Teen drama films, which usually consist of "finding self-identity", usually talk about how the teenagers survive, trying to fit in the society so they can be accepted as another identity. My creative work is about a girl who has been compared by her mother to her sister since her childhood and also being bullied because she does not have good grades, thus leads her to grow into a ball of inferiority and lose herself. She goes on a journey with her punk friends to find her father and finally, she finds her true self. The main subject matter for this creative work is self-identity. However, the theme is how social environment can make people feel inferior and shape someone's identity. The theory used for this work is 'Stages of Psychosocial Development' by Erik Erikson. This theory helps to find the crisis inside a specific range of ages when the stage is not met.
\end{abstract}

Keywords: Self-Identity, Teen Drama, Teenagers, Comparison, Bullying, Punk community.

\section{INTRODUCTION}

I have been intrigued by how screenplay writers write their screenplay and put it into a media called "movie" since I was in elementary school. Until now, I still love to watch many movies, all sorts of genres including drama, romance, comedy, horror, and even animations or short movies. By watching movies, it can give many benefits such as relaxation, overcoming fears, drives motivation, develops creativity, improves personal relationship, or even for entertainment purposes (Film Therapy, 2016). Because of my huge interest in how screenplay writers write their screenplays, I would like to create a screenplay as my final project. I choose a screenplay because a screenplay is more action and dialogue based rather than novel. Furthermore, the readers can notice the development of all characters through their actions and dialogues.

There are many genres in the screenwriting industry. For my creative work, since I am interested in the drama genre, I am using teen drama as the subgenre of this creative work. Teen drama tells about "adolescence, growing up, and the trials of youth" (Teen drama, n.d.). There are many subject matters for teen dramas, from young love, friendship, or even family problems. However, since finding a self-identity is an important inside the life of a teenager, I choose selfidentity as the subject matter for the creative work.

I am currently working on the effects of poor treatment of the societies in shaping the identity of a person, which can lead to identity crisis. Identity, based on PsychologyToday.com, "relates to our basic values that dictate the choices we make (e.g., relationships, career). These choices reflect who we are and what we value," (Heshmat, 2014). So, it is all about our social life and it reflects who we are as a person. However, when one person is confused about their role in life, it is called identity crisis. Identity crisis, according to Erik Erikson, "is a time of intensive analysis and exploration of different ways of looking at oneself," (Cherry, 2016). It is one of the most important conflicts that adolescences face in developing their mind and personality. One of the ways of how a person looks at oneself is to look at how people treat them. As an example, bad parenting and poor peers' relationship can lead to bad identity. They will be confused as to who they are and if they really should fit in inside of a community. As mentioned in a journal called 'Identity Development From Adolescence to Adulthood', "Differences in parenting styles will be reflected in differences in pathways of identity formation," (Becker, 1964, p. 345). Based on the research conducted by Alan S. Waterman, a psychology professor at The College of New Jersey, "individuals with permissive, neglecting, or rejecting parents may be expected most frequently to 
be identity diffuse and to have difficulty in successfully resolving identity crises should they occur," (Waterman, 1982, p. 345). Looking at this, how parents' nurture their children can make different personalities in the future. Also, "The nature of the social expectations pertaining to identity choices arising within the family, the schools, and the peer group will contribute to the particular identity development pathways employed," (Waterman, 1982, p. 345). Therefore, as an example, for adolescents having expectations to change in a society leads them into becoming somebody who they are not. They are forced mentally to shape into another identity when they are inside a community.

In my creative work, I inserted the element of punk community. I choose punk community because punk community has been the most underrated community. People would think that the punkers (a nickname for a group of punks, especially in Surabaya) are bad. I would like to show the readers that punk community is not as bad as they look. I would like to show the reader that looks do not really define their identity as bad or good. In one of the researches conducted by Anditya Arifarheza, a former Sociology student from Airlanga University Surabaya, people in the punk community in Surabaya do good things such as social services (Arifarheza, 2017). He reported that some of the punk community members in Surabaya are giving takjil (a small sweet meal to eat that people give during the Ramadan time), buying grains of rice and donate them to any institutions, or even helping the PKL (Pedagang Kaki Lima, street vendors) do a demonstration when they are being forced to leave the place (Arifarheza, 2017, p. 15). In other words, their looks do not define who they are. As mentioned in the research paper, people outside of the community judge them only by their looks (Arifarheza, 2017, p. 15). In my opinion, people should not judge people badly just because of their clothing or hair. Even though, yes, they sometimes do harmful things such as spraypainting walls, riots, or even destroying things. However, they do it because they feel neglected by the people outside of their community just because of their look and how they act (Arifarheza, 2017, p. 15). Hence, the spraypainting, riots, or destroy things are their way of responding to the hate.

My target audience is teenagers. I pick teenagers as my target audiences because they can relate easily with what Felicia does and thinks. Based on a research, "as adolescents develop more advanced patterns of reasoning and a stronger sense of self, they seek to forge their own identities, developing important attachments with people other than their parents" (Baumeister, 1986). They are searching for their identities because they are confused about which community or social structure they should be in or who they actually are.

My creative work tells about the story of Felicia, a senior high school student who is becoming more inferior after years of tiring comparison with her "perfect" sibling. One day, she goes on a journey to find her own self. This creative work is a full screenplay, which is around 60 pages long.

Inferiority and searching for identity are two serious problems in high school society nowadays. I am curious to know how teenagers with a bad environment in their childhood create their personality and how bad relationships between them and their parents affect their identity in their adolescent stage. In my work, I would like to explore 3 things which are how Felicia, a child who was raised poorly in her childhood, develops inferiority, how bad relationships between Felicia and her family and peers affect her in developing her identity, and how punk community can influence Felicia to be a better person.

For the purpose, I wish to show how teenagers build negative identity from bad environment and how bad relationships affect their self-identity. In my work, I want to show 3 things which that Felicia's family raised her poorly during her childhood stage which makes her inferior in her adolescent stage, that Felicia's relationships with her mother, sister, and peers affect Felicia's poor identity development, and that punk community is not as bad as they look and they can make someone to be a better person.

There are lots of teen drama movie about the journey of regaining one's self-identity. Movies such as "Mean Girls" and "The Perks of Being a Wallflower" are talking about an adolescent searching for their identity by fitting in with the popular, 'respectable' people. However, my creative work tells the story by bringing the element of punk community and lets the main character search for her father. Hence, the main character, which is Felicia, can grow and find her true self and home by leaving her comfort zone, which is her inferiority. As she uses her inferiority 
as a wall, to not grow into a better person, once she leaves her inferiority behind, she can find herself.

By showing the effects of bad treatment from peers and families to the main character, the readers would understand that environment can change someone's perspective of themselves and become inferior. The readers can see from the dialogues and actions later that the main character, Felicia, develops this negative identity because of all the bad treatment that affects her childhood development to adolescence stage.

I hope the readers can understand that our actions can change someone's perspective of themselves, making them more inferior and confused about themselves. I believe that the readers see the pain in Felicia's eyes on how her mother has been treating her differently since the very young age.

For my creative work, I am using the theory of Erik Erikson that is called "Stages of Psychosocial Development". Erik Erikson was a German-American psychologist in the 20th century who was known for his theory of psychological development of human being and the concept of an identity crisis.

This theory is about the stages of development of human being. There are 8 stages in the human being development. Furthermore, inside each stage, there are Psycho Social crisis. According to Erik Erikson, all of us face a certain crisis that contributes to our psychosocial growth (Erik Erikson's Theory of Psychosocial Development, 2017). For my creative work, I am using two stages only. I am using the fourth and the fifth stage.

The fourth stage is when the kids are 5 to 13 years. This is where they learn to write and do things on their own. In here, not only parents, but teachers also take a significant role in the child's life in teaching certain skills (McLeod, 2017). Since they are learning to do things on their own, they will actually feel the pride of accomplishing something when they do something by themselves. However, if these things are being restricted by teachers or parents, the child will begin to develop the feelings of inferiority and doubting their own potential.

The fifth stage occurs in the age of 13-21 years old. This is where adolescents search for their own identity, or more like self-discovery. They are expected to develop their sexual identity, whether they are men or women (Erik Erikson's theory of psychosocial development, 2017). That is why, in here, they may feel identity crisis as a result of the child to adult transition. Furthermore, here the children are becoming more independent and looking forward to their future career, relationship, families, and etc. Erikson claims that, "the adolescent may feel uncomfortable about their body for a while until they can adapt and "grow into" the changes" (Erik Erikson's theory of psychosocial development, 2017). However, when someone is pressuring them into an identity that they are not, they will produce a negative identity and becoming more rebellious, in addition to their feeling of unhappiness (Erik Erikson's theory of psychosocial development, 2017).

Erikson also said that "unhealthy individuals will spend their lifetime attempting to deal with the conflicts and challenges that emerge as a result of their failure to pass through earlier stage or stages" (Baker-Smith \& Moore, 2001, p. 20). Hence, when the child is experiencing poor treatment from their parents or teachers, or even their peers, their happiness in a stage will not be met and it will continue to haunt them in the next stage.

In another research conducted by Kerryn-Baker Smith \& Kathleen A Moore, both professors from the School of Psychology in Deakin University, Melbourne, Australia, because of poor parenting skills and incorrect parenting styles, the children can lack social skills and have fewer opportunity in socializing with their peers. Also, it increases their social anxiety (BakerSmith \& Moore, 2001). Looking at this, having a social anxiety means that the person feels more inferior compared to other kids. In the end, they will develop inferiority and low self-esteem, also feelings of inadequacy, especially in the age of 6-12 years (David, 2014). Another thing from the research is that if any stages or just one of the stages is not met, it will affect the other stage subsequently. That means their next stage of life will be affected too and will be interrupted (Baker-Smith \& Moore, 2001).

In my creative work, Felicia has been experiencing inferiority since her younger age, where her mother had been comparing her to her older sister and treated her poorly everyday for almost 10 years. Up to the present, her mother always compares her to her older sister by mentioning that her older sister can do anything better than her. Her mother also hurts her (grabs 
her hair, etc). Hence, it leads to Felicia believing that she is not perfect and she is less capable of doing anything good. After that, she develops low self-worth and self-esteem, and those lead to inferiority that makes her unable to socialize like other kids would do. Also, she has experienced bad treatment from her peers since a very young age because of her parents' divorce. She becomes more confused of her own identity because everyone keeps saying that she does not have a father and maybe she is not even her mother's daughter to begin with. She does not even feel like she is in the right home. When she is in the 2nd year of high school, she becomes more afraid of the society because of being bullied. This is where her inferiority deepens because of the previous stages of psychosocial development has not been met.

\section{OUTLINE OF THE CREATIVE WORK}

\subsubsection{Theme}

The subject matter of the creative work is self identity. The theme of my creative work is how a destructive relationship between a child with their parents and peers can develop inferiority and change their identity throughout their lifetime. Throughout the screenplay, the readers will be able to see how a teenager, when they are being controlled by their parents, they will be someone who they are not, develop inferiority, and have negative identity.

\subsubsection{Pitch}

1. Because of bad treatment from her mother since a very young age and being bullied by her peers in school, Felicia wants to move to her father's house in Solo.

2. Her mother keeps on prohibiting her to even talk about her father so she asks for help from her punk friends to go to Solo.

3. At last, she breaks her own heart when she finally finds her father in Solo and realises that her father is not the person she hopes to meet and her punk friends are the only people who accept her for who she is and make her feel at home.

\subsubsection{Synopsis}

Felicia, 16, a lonesome and quiet girl, is living with her mother and her older sister. Her parents got divorced when she was 6 years old. Her mother treated her poorly by comparing her to her older sister so she has the desire to move to Solo, to her father's house. However, her mother always prohibits her even to talk about her father or mentioning his name. Her peers in school do not care about it and even bully her because her parents' divorce. The only people who care are her punk friends from the punk community. Hence, she asks her punk friends to help her find her father. In the end, after she finds her father, she realises that her true 'home' is in the punk community, not even her own family.

\subsubsection{Characters}

1. Main Characters:

- $\quad$ Felicia Wiyono

Age: 16 years old

She is the youngest child on Wiyono's family. She is the daughter of Harris Wiyono and Dewi Pradipta. She has medium-toned skin. Ever since her parents divorced, she started to become a loner. She rarely talks to anyone. Whenever she is in school, she goes somewhere quiet so she won't be bullied by her peers. She is also a crybaby. She gets bullied because she is not that smart and because she doesn't 'have' a father. Her true delinquent self starts when her mother prohibits her from contacting her father in Solo and meets Ricky. She is quiet. But once she talks, it pierces the heart.

Dewi Pradipta

Age: 40 years old 
A widow. Once married to a man named Harris Wiyono. She is the mother of Jessica and Felicia. She is very strict and has the tendency to push others for her own goal. She has been comparing Felicia to Jessica since their childhood. She is working as a catering owner.

Ricky

Age: 16 years old

He is the leader of a small punk community in Surabaya. He is the leader of the punk community. He is very tall and looks like a model. His face is very handsome. He always keeps his promises to her and stays true to himself and his friends.

2. Minor Characters:

- Jessica Wiyono

Age: 19 years old

She is the older sister of Felicia and the daughter of Dewi. She is very diligent, calm, and mature. She is currently a new college student.

Harris Wiyono

Age: 46 years old

He was the husband of Dewi Pradipta and the father of Jessica and Felicia. He lives in a huge house in Solo, together with his maid, mbak Susi. However, he has a prostitution business that he kept a secret from Felicia.

- Dela

Age: 16 years old

She is the captain of class $11 \mathrm{C}$. She is socially awkward, yet a smart-ass. She is the only person who tries to talk to Felicia in class because she thinks that Felicia needs a friend.

Patricia

Age: 16 years old

She is the leader of bullies in school. She is popular.

- $\quad$ Susi

Age: 30 years old

She is the house-maid of Harris in Solo. She is nice, friendly, yet very secretive about Harris' work to Felicia.

\subsubsection{Settings}

1. Senior High School

The school is a mid-sized, three storey prestigious school. It is located in the East of Surabaya. The hallway is very clean and the school has its own auditorium. Each class consists of 25 to 35 students only. The backyard is large in size. The canteen is pretty big for a medium-sized school.

2. Dewi Pradipta's home

This is the household of Dewi Pradipta's family. This home is located in Surabaya east, near Sentosa High School. The house is a mid-sized home with a Victorian touch to its interior. Since it is close to the high school, Felicia has always walked to school since elementary days.

3. Harris Yuwono's home 
Harris' house is extremely huge and there is a security post in front of it. The gate of the house is big and black. All of the room except the guest rooms are big. The house is located in Solo, a bit far from Solo Balapan train station.

\section{Abandoned Hideout}

There are two hideouts in this creative work. One is in Surabaya and one in Solo. The hideout is not that big. However, it can fit 8 to 10 people. The one in Surabaya is dirtier than one in Solo. There are tables and chairs for them to make things or do discussions.

\section{Boarding House}

This boarding house is located in Solo, used by Harris Wiyono for a secret prostitution service where all the girls are young and sexy. The building is mid-sized and has many windows. It is quite a distance from Harris' house and that is why he has to leave early in the morning.

\section{CONCLUSION}

I would like to explain the lessons that I learned after making this creative work and my final thoughts about it.

I learned that making a full screenplay (60 pages) is extremely hard. Not only did I have to think about the huge plot (since there has to be many actions and dialogues), but I had to do research about the format of a screenplay. There are lots of new terms that I learned and some of them are "FADE TO FLASHBACK", "INTERCUT", and "CUT TO". "FADE TO FLASHBACK" is used when we want to insert a flashback inside a screenplay. "INTERCUT" is when we want to make a phone call scene, where there are two or more people talking in different places in the same time. Finally, "CUT TO" is used when we want to jump from one scene to another scene directly. Those three screenplay elements helped me make this creative work even better.

Also, I did not have an interesting plot before. I was going to have that Felicia does not meet her father. However, one of my lecturers gave me an idea that it is okay to have the main character reach her goal. Hence, I made her meet her father. She reaches her goal to meet her father, although it breaks her heart into pieces because her father is not the person she dreams of.

Another thing that I learned is that journals are tremendously helpful. Different to books, journals are more precise. The writers read many books and gather people's opinion from other journals. They also conduct research before making the journals. In my opinion, journals are more fun to read since there are many research titles inside one journal, rather than a non-fiction book.

However, one of the most intriguing things I learned is that the punk community is not that bad. People always think that the punks are bad, hideous, and mischievous. However, after I did lots of research on them, they are actually not that bad. They are also human beings like us. The difference is that they have their own way in showing their feelings for the government or the people around them. They could not show it with words, so they show it much more through their actions. It is truly just the way they act and how they approach people differently compared to us.

To conlude all of this, Making this creative work is actually something that I thought I would never do. From doing research, asking my lecturer for ideas, and typing non-stop everyday; these are actually things that I rarely do in my whole life.

This creative work is to show that poor treatment from parents, peers, or any other person can make a person feel inferior. Also, inferiority kills. Not only does it kill the chance for someone to grow to be a better person, but it kills the happiness of a person. Inferiority makes people forget about their own self worth and they cannot find their true identity since they do not love themselves because of others' action and speeches toward them. Parents and peers are two of the factors that lead someone into changing their identity or being confused with their identity. Since they are always together on daily basis, parents and peers often become the cause of an adolescent having an identity crisis.

By using Felicia as the main character, who has been inferior since a very young age, I hope the readers understand that harsh, unkind words and doings are killing some people mentally. People with inferiority or without can be destroyed by a single word or a small sentence. Inferiority can grow inside them little by little and it makes feel them unworthy. Afterwards, they will feel that 
they do not belong in any community. They feel the need to hide inside their cocoon and never leave their comfort zone allowing them to grow.

\section{REFERENCES}

Arifarheza, A. (2017). Perilaku Anggota Komunitas Punk di Surabaya. (chap. 4). Jurnal Online Sosiologi FISIP Unair: Komunitas (p. 15). Surabaya: UNAIR.

Baker-Smith, K. \& Moore, K. (2001). Early onset of social anxiety: Impact on Erikson's stages of psychosocial development. Relationships: Their impact on social and mental. (19-23).

Baumeister, R. F., \& Tice, D. M. (1986). How adolescence became the struggle for self: A historical transformation of psychological development. In J. Suls \& A. G. Greenwald (Eds.). Psychological perspectives on the self (Vol. 3, pp. 183-201). Hillsdale, NJ: Lawrence Erlbaum Associates.

Cherry, K. (September 10, 2016). What is an identity crisis. Retrieved on Monday, March 19, 2018 from https://www.verywellmind.com/what-is-an-identity-crisis-2795948

David, L. (July 23, 2014). Erikson's stages of development. Retrieved on March 6, 2018 from https://www.learning-theories.com/eriksons-stages-of-development.html

Driscoll, C. (June, 2011). Teen film: A critical introduction. Oxford, New York: BERG press

Erik Erikson's theory of psychosocial development. (May 19, 2017). Retrieved on March 5,

2018 from https://www.psychologynoteshq.com/erikerikson/

Field, S. (n.d.). The use of flashbacks in movies. Retrieved on July 3, 2018 from https://www.writersstore.com/the-use-of-flashbacks/

Film therapy: the benefits of watching movies. (November 29, 2016). Retrieved on November 16, 2017 from https://exploringyourmind.com/film-therapy-benefits-watching-movies/

Heshmat, S. (2014). Basic of Identity. Retrieved on June 10, 2018 from https://www.psychologytoday.com/us/blog/science-choice/201412/basics-identity

McLeod, S. (2017). Erik Erikson. Retrieved on March 6, 2018 from https://www.simplypsychology.org/Erik-Erikson.html

Teen drama. (n.d.). Retrieved on March 4, 2018 from http://changingminds.org/disciplines/storytelling/plots/classic/teen.htm

Waterman, A. S. (1982). Identity development from adolescence to adulthood: An extension of theory and a review of research. Developmental Psychology, 18(3), 341-358. 